\title{
Recent trends in sea surface temperature off Mexico
}

\author{
S. E. LLUCH-COTA, M. TRIPP-VALDEZ and D. B. LLUCH-COTA \\ Centro de Investigaciones Biológicas del Noroeste (CIBNOR), A.P. 128, 23000 La Paz, Baja California Sur, México \\ Corresponding author: S. E. Lluch-Cota; e-mail: slluch@cibnor.mx \\ D. LLUCH-BELDA \\ Centro Interdisciplinario de Ciencias Marinas, Instituto Politécnico Nacional (CICIMAR-IPN), A P. 592, 23000 \\ La Paz, Baja California Sur, México
}

\begin{abstract}
J. VERBESSELT
Wageningen University and Research Centre, Laboratory of Geo-information Science and Remote Sensing, P.O. Box 47, 6700AA Wageningen, The Netherlands
\end{abstract}

H. HERRERA-CERVANTES

Centro de Investigación Científica y Educación Superior de Ensenada, Unidad Baja California Sur (CICESE-La Paz), Miraflores 334, Fracc. Bella Vista, 23050 La Paz, Baja California Sur, México

J. J. BAUTISTA-ROMERO

Centro de Investigaciones Biológicas del Noroeste (CIBNOR), A.P. 128, 23000 La Paz, Baja California Sur, México

Received August 20, 2012; accepted August 15, 2013

\section{RESUMEN}

Los cambios de temperatura promedio del océano a nivel global tienen el potencial de afectar negativamente los sistemas naturales y socioeconómicos actuales; sin embargo, los registros para proyectar las tendencias de cambio a nivel regional son escasos y, en algunos casos, contradictorios. En este estudio se analizan las señales de cambio de la temperatura superficial en mares mexicanos, y se comparan con otras regiones del planeta y con indicadores climáticos clave, tanto del Pacífico Norte como de la franja tropical en el Atlántico y el Pacífico. Se identificaron ocho regiones con diferente exposición a la variabilidad climática: en el Pacífico, la costa occidental de la península de Baja California no muestra una tendencia clara, el Golfo de California exhibe una tendencia modesta de enfriamiento durante los últimos 20 a 25 años, en la parte más oceánica del Pacífico mexicano se nota una tendencia intensa de enfriamiento, la región más tropical muestra una tendencia intensa de calentamiento, y entre ambas regiones se forma una banda de transición sin tendencia; en el Atlántico, la parte noreste del Golfo de México muestra una tendencia de enfriamiento, en tanto que la parte oeste, junto con el Caribe, se han estado calentando por lo menos durante los últimos 30 años. Se analizan las interacciones potenciales de estas tendencias con algunas pesquerías principales y la presencia de ecosistemas costeros sensibles.

\begin{abstract}
Changes in global mean sea surface temperature may have potential negative implications for natural and socioeconomic systems; however, measurements to predict trends in different regions have been limited and sometimes contradictory. In this study, an assessment of sea surface temperature change signals in the seas off Mexico is presented and compared to other regions and the world ocean, and to selected basin scale climatic indices of the North Pacific, the Atlantic and the tropical Pacific variability. We identified eight regions with
\end{abstract}




\begin{abstract}
different exposure to climate variability: In the Pacific, the west coast of the Baja California peninsula with mostly no trend, the Gulf of California with a modest cooling trend during the last 20 to 25 years, the oceanic area with the most intense recent cooling trend, the southern part showing an intense warming trend, and a band of no trend setting the boundary between North-Pacific and tropical-Pacific variability patterns; in the Atlantic, the northeast Gulf of Mexico shows cooling, while the western Gulf of Mexico and the Caribbean have been warming for more than three decades. Potential interactions with fisheries and coastal sensitive ecosystems are discussed.
\end{abstract}

Keywords: Climate change, trends, ocean temperatures, regional scale.

\section{Introduction}

The global mean sea surface temperature (SST) has increased more than $0.67^{\circ} \mathrm{C}$ during the last 100 years (Trenberth et al., 2007). Due to this observed tendency and its potential negative implications for natural and socioeconomic systems, several major international scientific organizations and many individual scientists are devoting a great deal of time and efforts to the challenge of measuring, understanding, and forecasting climate change and its impacts. Scientific information on climate change has been dramatically increasing during the last few decades, as reflected in the series of four assessments published by the Intergovernmental Panel on Climate Change in 1990, 1995, 2001 and 2007 (the fifth assessment is expected to be published in 2013/14). However, those same documents still have large data gaps that need to be filled during the upcoming years in order to better understand climatic changes.

Ecological, social, and economic sciences are committed to identifying and designing strategies for the adaptation of human societies and their production systems to potential future climate conditions. To accomplish that, the consideration of climate change scenarios as proposed by climate modeling is a relevant activity, but understanding how the systems have functioned and changed in the past is essential for actual predictability. Still, most analyses are centered in the evaluation of the sensibility of ecological or socioeconomic systems, while exposure is seldom measured.

In this contribution we approach what we believe is a major gap in the knowledge-building process around the climate change: the measurement of exposure. We are interested in the ocean realm because even when marine ecosystems provide essential benefits, such as provisioning of food and other goods, climate and natural hazards regulation, cultural, and supporting
(Millennium Ecosystem Assessment, 2005), they have largely been underrepresented in the majority of climate change reports. In Mexico, for example, there is virtually no mention of marine ecosystems within the series of national communications to the United Nations Framework Convention on Climate Change (UNFCCC). This situation is similar at the global scale. It is surprising that the upcoming fifth assessment of the IPCC will be the first of the series to host ocean chapters with assessments of impacts and adaptation, both as sectors and as a region.

In this study we investigated the spatial signature of the exposure because we know that global warming is not homogenous in time nor space (Trenberth et al., 2007; Falvey and Garreaud, 2009), and we expect the ocean surrounding Mexico to reveal particularly diverse trends even thought its seas are a relative small part of the world. Reasons include the proximity of two oceanographically independent basins (Atlantic and Pacific), and the presence of many different regional oceanographic regimes and ecological provinces (tropical oceans, coastal upwelling, major currents boundaries, etc.). In this regard, large part of the study region is in the transition between tropical and subtropical climate regimes, and exposed to large-scale modes of natural variability, such as El Niño/Southern Oscillation (ENSO), the Pacific Decadal Oscillation (PDO), the Atlantic Multidecadal Oscillation (AMO), and their interactions in time and space (Falvey and Garreaud, 2009; Deser et al., 2010).

\section{Methods}

The analysis is based on reconstructed sea surface temperature from the National Climatic Data Center (NCDC) in its latest version (NOAA_ERSST_V3 data, provided by NOAA/OAR/ESRL PSD, Boulder, Colorado [http://www.esrl.noaa.gov/psd/]). The data base, spanning from January 1910 to December 2011 
in monthly time steps, has a spatial resolution of $2 \times 2^{\circ}$. We excluded iced-oceans by extracting data only from $70^{\circ} \mathrm{S}$ to $70^{\circ} \mathrm{N}$. From the same website we downloaded the time series of the Atlantic Multidecadal Oscillation (AMO; Enfield et al., 2001), the Pacific Decadal Oscillation (PDO; Mantua et al., 1997), and the Trans Niño Index (TNI; Trenberth and Stepaniak, 2001), and plotted them with a five year moving average filter to explore similarities in the variability patterns.

To detect recent trends at each of the boxes we used the Breaks for Additive Seasonal and Trend (BFAST) method developed by Verbesselt et al. (2010) and available as an R package (R Development Core Team, 2011) from the Comprehensive $\mathrm{R}$ Archive Network (http://cran.r-project.org/package= bfast). This method integrates an iterative decomposition of time series into a trend, seasonal and noise components, and includes methods for detecting and characterizing changes (breakpoints) within time series. An additive decomposition model is used to iteratively fit a piecewise linear seasonal and trend model. The number and position of the breakpoints are estimated from the seasonally adjusted data ( $Y t$ - $\hat{\mathrm{St}}$ ) with the method proposed by Bai and Perron (2003), which minimizes the Bayesian information criterion (BIC) to determine the optimal number of breaks and iteratively minimizes the residual sum of squares to estimate the optimum break position. Verbesselt et al. (2010) give a full description and validation of the method, which has been applied as a normalized difference vegetation index (NDVI; Verbesselt et al., 2010, 2012; de Jong et al., 2012). We tested the method suitability for monthly temperature values.

The method requires definition of the minimum section of the series to fit a piecewise linear model. Here we selected a period of 10 years of monthly temperature data as the minimum period, which means that only piecewise linear segments of at least 10 years will be identified. We specially focus on the most recent piecewise linear trend segment identified as indicator of recent exposure to changes in climate. We then mapped the slope (changing rate) and length (number of years) of the analytically detected recent trend, and computed the total change (their product in ${ }^{\circ} \mathrm{C}$ ) for the subset covering from 10 to $35^{\circ} \mathrm{N}$ and 120 to $80^{\circ} \mathrm{W}$. We also compared the relative frequency distribution of total change to four other areas, and the global.

\section{Results and discussion}

Figure 1 shows eight time series of SST anomalies of the $2 \times 2^{\circ}$ boxes selected as representative of each region identified in Figure 2c (i.e., individual series selected from the core of each of the visually identified region), to visually show what we define as recent trends. For these series, we plot the monthly anomalies time series (seasonal cycle removed) together with the partial trends as resolved by the BFAST, and in solid line the recent trend. As shown by the eight individual time series, there are differences in the number and length of trends between series. These large differences are also evident from the maps in Figure 2, as slope (Fig. 2a), length (Fig. 2b) of the last trend, and the estimated total change (Fig. 2c). This figure reveals, as we expected, there are highly contrasting regional behaviors within a relatively small part of the ocean. We consider the lower panel to represent exposure to recent changes in climate.

\subsection{Regions \\ 3.1.1 Pacific region}

The northernmost part of the Pacific side (Fig. 2c, region around mark "a") shows no trend during the last 10 to 15 years (slope value close to 0 ). This region corresponds to the southern part of the California Current System (CCS), which is largely influenced by seasonal coastal upwelling. According to the California Cooperative Oceanic Fisheries Investigations (CalCOFI) data, this region has been characterized by a shift from warming to cooling trends (Bograd and Lynn, 2003) as consequence of natural fluctuations rather than an effect of global warming (Di Lorenzo et al., 2005). However, since upwelling in the southern CCS is driven by a wind stress curl along the California margin, global greenhouse warming would increase the ocean-land pressure gradient, increasing wind stress and leading to an intensification of upwelling (Bakun, 1990; Snyder et al., 2003). Even when a warming trend was not detected in the southern CCS with the BFAST method, other consequences of climate change, such as shelf hypoxia conditions, that have been well documented for some upwelling systems (Helly and Levin, 2004; Monteiro et al., 2008) have been recently reported to be increasing in the CCS (Feely et al., 2008; Connolly et al., 2010). There is a strong interest in testing whether this conditions are linked to mass mortality events of highly valuable benthic resources (Gutiérrez et al., 2011), and to 


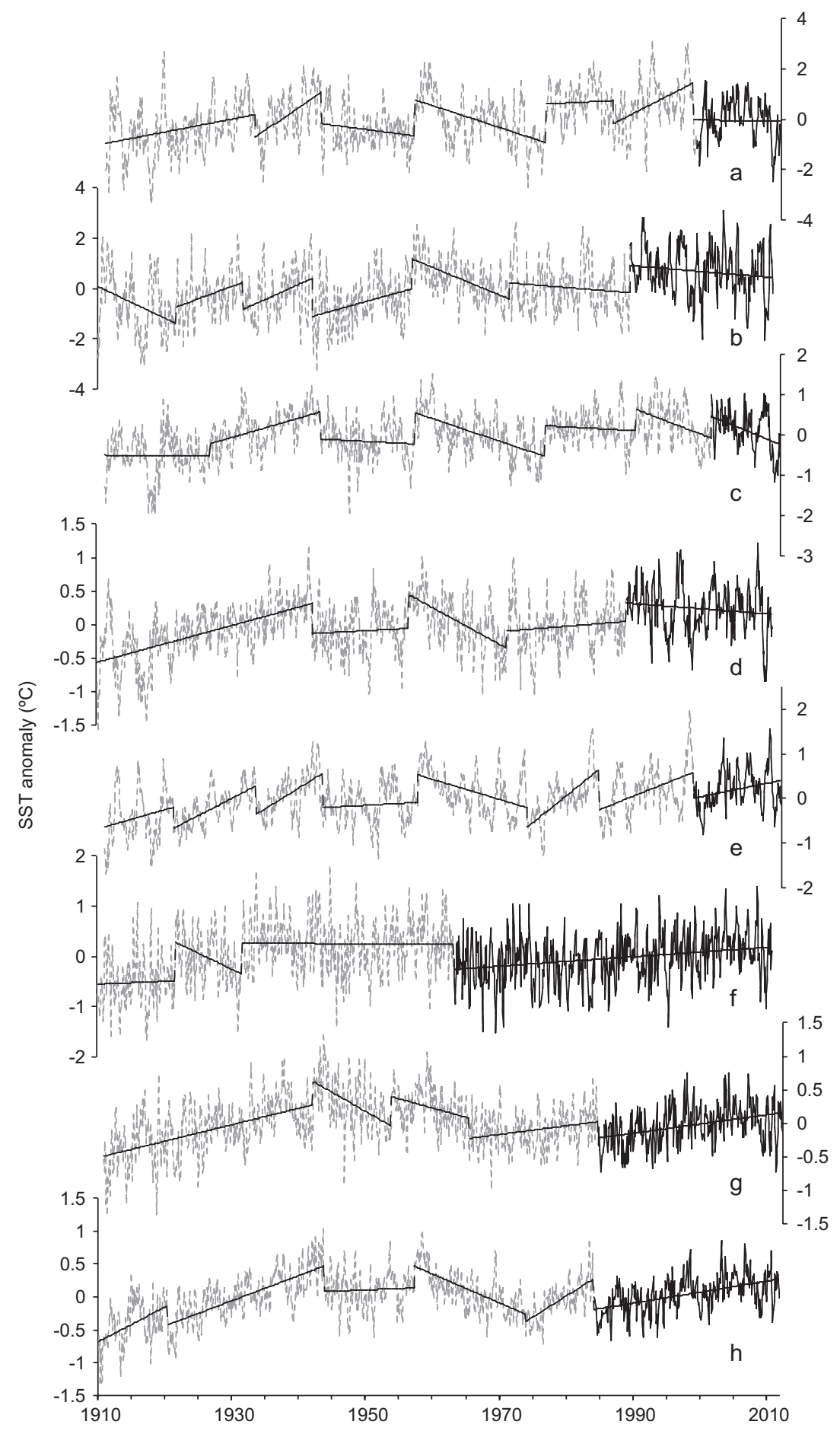

Fig. 1. Sea surface temperature anomalies time series of selected $2 \times 2^{\circ}$ boxes representing the eight regions identified as having distinct recent trends. The coordinates for each box center are listed in Table I, and graphically shown in Figure 2c. The most recent trend is highlighted in bold. 

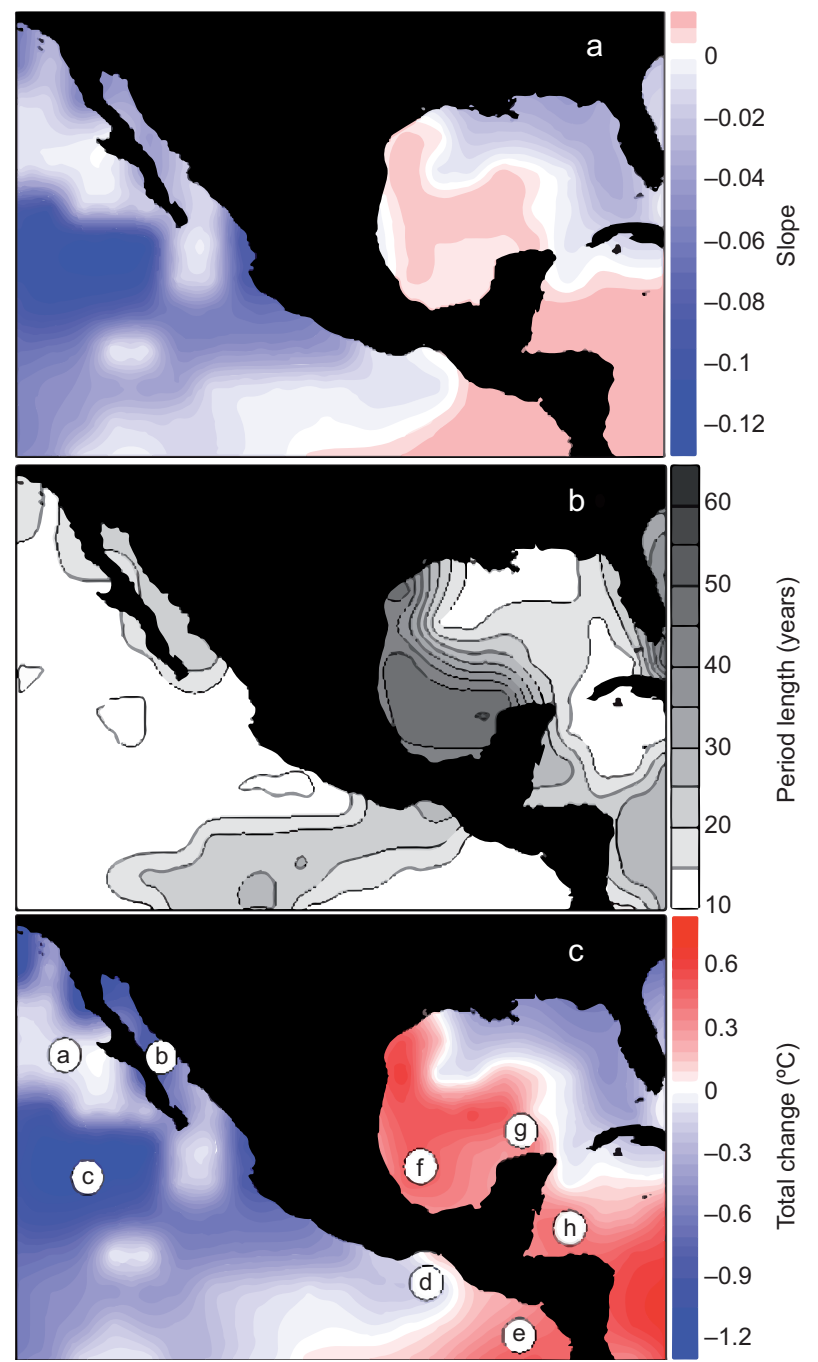

Fig. 2. Spatial distribution of the most recent fitted piecewise linear trend segment shown as slope (a), period length in years (b), and total change in ${ }^{\circ} \mathrm{C}(\mathrm{c})$.

understand the potential interactions of temperature changes and hypoxia in these environments.

For the Gulf of California (Fig. 2c, mark "b"), the analysis reveals a modest cooling trend during the last 20 to 25 years (Fig. 2b). This coincides with Lluch-Cota et al. (2010), who reported that for recent decades no significant sustained long-term trend was evident in any of the time series of physical and ecological variables considered by them. They also explained the apparent contradiction with the century-long analysis by Lluch-Belda et al. (2009) that reported a positive long-term warming, by considering only the second part of the century (since the early 1960s), when the global surface air temperature series shows the most dramatic warming, for which no significant trends can be detected and, in fact, the slope is negative.

The Pacific far ocean area (Fig. 2c, region around mark "c") represents the region with the most intense recent cooling trend. This region is under the influence of the North Pacific central gyre (the southernmost limit of the eastern boundary component and the eastward turn), and the north equatorial counter current; future oceanographic studies might shed light on this recent cooling, but it is seemly related to the basin wide variability, as suggested by the PDO (Fig. 3, second series). The southernmost region of the Pacific side of our study area (Fig. 2c, region around mark "e") shows a clear warming trend occurring during the last 10 to 15 years. This region is fully dominated by tropical conditions and is largely influenced by the ENSO dynamics and the Pacific warm pool. While long warming trends have been predicted for the future (An et al., 2011), the trans El Niño index, which is the difference between the normalized SST anomalies averaged in the Niño$1+2$ and Niño-4 regions (Threnberth and Stepaniak, 2001), suggests that trends are not monotonic in the long term, and that variability is largely dominated by the high frequency.

Between the Pacific far ocean and the southernmost region, one can identify an interesting band of neutral change conditions occurring during at least the last 20 to 30 years (Fig. 3c, around mark "d"), somehow setting the boundary between North-Pacific-like and tropical-Pacific-like variability patterns.

\subsubsection{Atlantic region}

The Atlantic side of our study region includes the western Caribbean Sea and the entire Gulf of Mexico. We found that the northeast Gulf of Mexico is cooling, at least during the last 10 to 20 years, while the western Gulf of Mexico (Fig. 2c, mark "f") and the Caribbean region (mark " $h$ ") have been warming for more than three decades. The oceanographic region that delimits the two areas coincides with the position of the loop current which connects the Yucatan and the Florida currents. Although this process can be considered as one of the key linkages between the North Atlantic and South Atlantic waters, the differences in trends suggest that different processes may have an influence. Chollett et al., (2012) analyzed 25 years of satellite data (1985 to 2009) for the Caribbean Sea and the southeastern Gulf of Mexico, and reported an average trend of $0.29^{\circ} \mathrm{C} /$ 

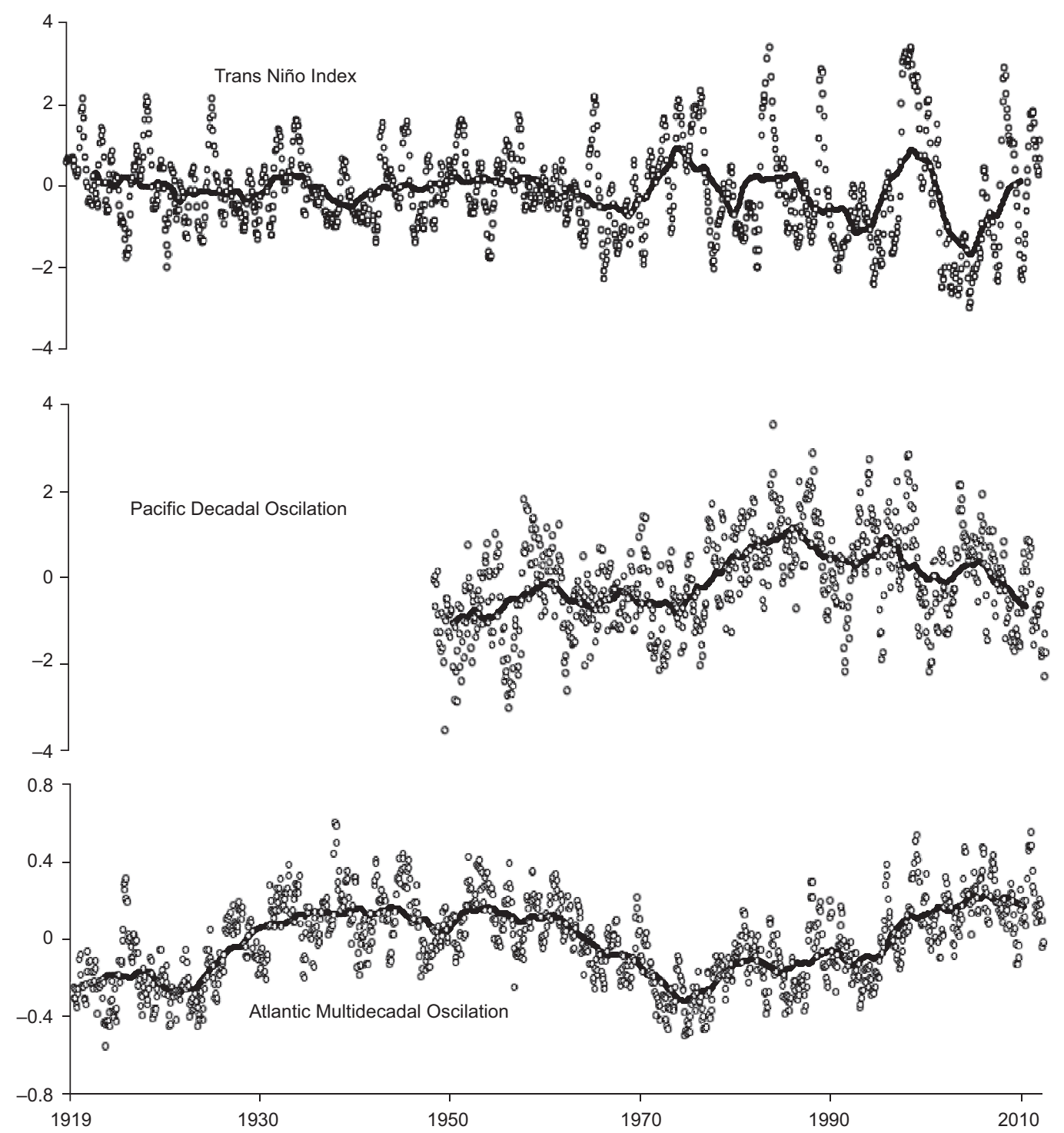

Fig. 3. Raw (dots) and filtered (5-yr moving average) time series of basin scale ocean climate indices. Data was downloaded from the NOAA/OAR/ESRL PSD, Boulder, Colorado website (http://www.esrl.noaa.gov/psd/).

decade, which lies within the range of 0.2 and 0.6 ${ }^{\circ} \mathrm{C} /$ decade found by Strong et al. (2008) based on the period 1985 to 2006 , and close to the estimation by Good et al. (2007), who reported $0.3{ }^{\circ} \mathrm{C} /$ decade for the period 1985 to 2003 . We found values between 0.05 and $0.27{ }^{\circ} \mathrm{C} /$ decade for the boxes with positive trend within the Atlantic side of our study period. It should be noted that due to the nature of the data (low spatial resolution), and the analysis (variable trend period for each box), there are differences between our study and those cited above, that should be considered when interpreting the comparison.

Chollett et al. (2012) reported that when using high resolution data, the region exhibits spatially heterogeneous trends. They found warming to be greatest in the tropical Atlantic and eastern Caribbean Sea and in the loop current region, in the eastern Gulf of Mexico, and found non-significant SST changes off Florida, Cuba and the Yucatán Peninsula upwelling area. This contrasts with our description, since we found negative trends for the northeast Gulf, and basically no trends for the loop-current region. However, in the Caribbean region (warming), our data coincides with them and with the close to no trend values off Cuba. Also, we found that our data agrees with Chollett et al. (2012) regarding the Yucatan 
upwelling, showing no trend, which contrasts with the ongoing debate about a generalized wind-driven upwelling that causes an increased SST trend (Bakun, 1990). This is supported by Bakun et al. (2010) and Demarcq (2009), but once again contrasts with data from others such as Pérez et al. (2010). The upwelling area in the Atlantic off Mexico shows no significant trend in SST, suggesting that the forcing factors of upwelling activity are relatively constant.

By visually examining the Atlantic Multidecadal Oscillation time series (Fig. 3, third series), it is clear that the century-long time series are strongly dominated by this variability pattern. Further, other variability indices such as the Caribean SST index (Penland and Matrosova, 1998) and the Atlantic tripole (Deser and Timlin, 1997) also show the gen- eral multidecadal pattern as capturing a large portion of the variability. If this mode of variability continues to be dominating in the next decades, and if the amplitude and phase of the oscillation are conserved, the region will exhibit a decrease in the warming trend for a couple of decades, and will tend to cool thereafter. However, strong uncertainty on the dates and amplitudes derives from the fact that we have only clearly documented one complete cycle of this oscillation, and our understanding is far from sufficient.

\subsection{Comparison of the frequency distribution}

Figure 4 shows the relative frequency distribution of total change values (the product of last trend period length and its slope at each of the $2 \times 2^{\circ}$ boxes included in the polygon) for the ocean around Mexico,

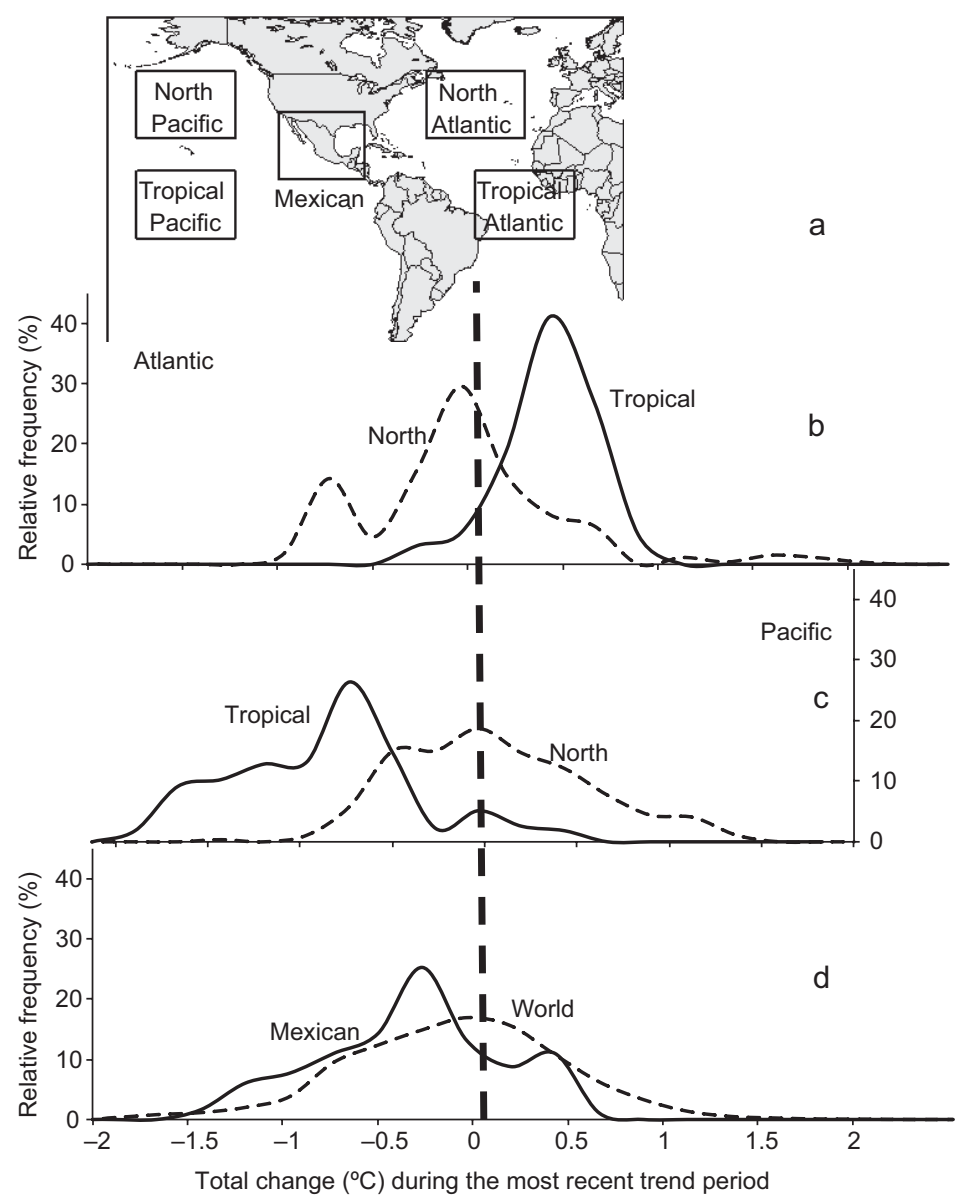

Fig. 4. Relative frequency distribution of recent temperature change estimates (product of the slope and period length of the most recent fitted piecewise linear trend segment at each $2 \times 2^{\circ}$ quadrant) for the ocean around Mexico, other four regions in the north and tropical Pacific and Atlantic oceans, and the entire world ocean (polar seas excluded). Coordinates are listed in Table I. 
Table I. Geographic references for the analyses and comparisons. The $2 \times 2^{\circ}$ boxes correspond to letters in Figure $2 \mathrm{c}$ and are considered representative of eight regions with a particular recent temperature trend within the oceans around Mexico. Polygons correspond to large ocean areas and are shown in Figure 4a.

\begin{tabular}{ccc}
\hline $2 \times 2^{\circ}$ boxes & Longitude $\left({ }^{\circ} \mathrm{W}\right)$ & Latitude $\left({ }^{\circ} \mathrm{N}\right)$ \\
\hline $\mathrm{a}$ & 116 & 26 \\
$\mathrm{~b}$ & 110 & 26 \\
$\mathrm{c}$ & 112 & 18 \\
$\mathrm{~d}$ & 94 & 14 \\
$\mathrm{e}$ & 88 & 12 \\
$\mathrm{f}$ & 94 & 20 \\
$\mathrm{~g}$ & 88 & 22 \\
$\mathrm{~h}$ & 86 & 18 \\
\hline
\end{tabular}

Large areas (polygons)

\begin{tabular}{lcc}
\hline Oceans off Mexico & $120-85^{\circ} \mathrm{W}$ & $10-35^{\circ} \mathrm{N}$ \\
North Pacific & $178-138^{\circ} \mathrm{W}$ & $25-50^{\circ} \mathrm{N}$ \\
Tropical Pacific & $178-138^{\circ} \mathrm{W}$ & $12^{\circ} \mathrm{S}-13^{\circ} \mathrm{N}$ \\
North Atlantic & $60-20^{\circ} \mathrm{W}$ & $25-50^{\circ} \mathrm{N}$ \\
Tropical Atlantic & $40^{\circ} \mathrm{W}$ to $0^{\circ}$ & $12^{\circ} \mathrm{S}-13^{\circ} \mathrm{N}$ \\
The world & All & $70^{\circ} \mathrm{S}-70^{\circ} \mathrm{N}$ \\
\hline
\end{tabular}

as compared to global ocean and four selected areas from the Pacific and Atlantic (Fig. 4a).

The distribution of temperature change for our study area shows cooling trend values of as much as $1.5^{\circ} \mathrm{C}$, and warming trend values of slightly over $0.5^{\circ} \mathrm{C}$. Close to $75 \%$ of the area shows negative trends, with a mode around $-0.3{ }^{\circ} \mathrm{C}$. The figure is aimed at demonstrating that the study area shows a wide range of behaviors in a relatively small region; however, when compared to the rest of the distributions it is clear that the heterogeneity is not exclusively found in this region. In fact, besides the tropical Atlantic, all regions have shown wide ranges of temperature changes within the recent changes in values. We have detected two modes in the distribution, one at each side of the range (positive and negative temperature changes), tending to correspond to the Pacific (cooling) and Atlantic (warming) distributions of the tropical areas of each basin.

It is beyond the scope of this contribution to analyze trends from other regions of the world, however we found it surprising that: (1) most of the area considered here as tropical Pacific shows a cooling trend during the recent period (mostly for the last 10-15 years); (2) the tropical Atlantic shows a more homogeneous distribution of warming during the most recent period (mostly longer than 20-25 years); (3) the northern Pacific and northern Atlantic had the majority of values close to no change, but still a relatively large proportion of the area showed temperature change values distributed in the opposite direction when compared to their tropical corresponding basin (North Atlantic showing cooling areas vs. mostly warming areas in the tropical Atlantic, and North Pacific having a warming portion of its area vs. mostly cooling areas in the tropical Pacific); and (4) the Earth's oceans (excluding the rapidly warming polar oceans) have most of their values showing a close to 0 trend, with similar fractions being distributed to the warming and cooling sides of the range.

\section{Conclusions}

Sea surface temperature around Mexico shows highly contrasting trends between regions. In the Pacific side, the west coast of the Baja California peninsula shows mostly no trend, the Gulf of California and the oceanic area have been cooling during recent decades, the southern Pacific showing an intense warming trend, and there is a band of no trend setting the boundary between North-Pacific and tropical-Pacific variability patterns. In the Atlantic, the northeastern Gulf of Mexico shows cooling, while the western Gulf of Mexico and the Caribbean have been warming for more than three decades. There may be important consequences of these tendencies for regional fisheries and sensitive marine ecosystems; however, any attempt to use observed recent trends to forecast changes in marine populations demands not only a deeper understanding of the mechanisms linking them, but also the development of climate prediction capabilities.

\section{Acknowledgments}

This paper is a contribution to the project CONACyTSAGARPA 126574. DLB received DEPI and SIBE fellowships. Dr. Miguel Córdoba helped with English editing.

\section{References}

An S., J. Kim, S. Im, B Kim. and J. Park, 2011. Recent and future surface temperature trends in tropical Pacific warm pool and cold tongue regions. Clim. Dynam. 39, 1373-1383, doi:10.1007/s00382-011-1129-7. 
Bai J. and P. Perron, 2003. Computation and analysis of multiple structural-change models. J. Appl. Econom. 18, 1-22.

Bakun A., 1990. Global climate change and intensification of coastal ocean upwelling. Science 247, 198-201.

Bakun A., D. B. Field, A. N. Redondo-Rodriguez and S. J. Weeks, 2010. Greenhouse gas, upwelling-favorable winds, and the future of coastal ocean upwelling ecosystems. Glob. Change Biol. 16, 1213-1228.

Bograd S. J. and R. J. Lynn, 2003. Long-term variability in the southern California Current System. Deep-Sea Res. Pt. II 50, 2355-2370.

Chollett I., F. E. Müller-Karger, S. F. Heron, W. Skirving and J. P. Mumby, 2012. Seasonal and spatial heterogeneity of recent sea surface temperature trends in the Caribbean Sea and southeast Gulf of Mexico. Mar. Pollut. Bull. 64, 956-965.

Connolly T. P., B. M. Hickey, S. L. Geier and W. P. Cochlan, 2010. Processes influencing seasonal hypoxia in the northern California Current system. J. Geophys. Res. 115, C03021.

De Jong R., J. Verbesselt, M. E. Schaepman and S. Bruin, 2012. Trend changes in global greening and browning: contribution of short-term trends to longer-term change. Glob. Change Biol. 18, 642-655.

Demarcq H., 2009. Trends in primary production, sea surface temperature and wind in upwelling systems (1998-2007). Prog. Oceanogr. 83, 376-385.

Deser C. and M. Timlin, 1997. Atmosphere-ocean interaction on weekly timescales in the North Atlantic and Pacific. J. Climate 10, 393-408.

Deser C., M. A. Alexander, S. P. Xie and A. S. Phillips, 2010. Sea surface temperature variability: Patterns and mechanisms. Ann. Rev. Mar. Sci. 2, 115-143.

di Lorenzo E., A. J. Miller, J. C. Schneider and J. C. McWilliams, 2005. The warming of the California Current System: Dynamics and ecosystem implications. J. Phys. Oceanogr. 35, 336-362.

Enfield D. B., A. M. Mestas-Nuñez and P. J. Trimble, 2001. The Atlantic multidecadal oscillation and its relation to rainfall and river flows in the continental U.S. Geophys. Res. Lett. 28, 2077-2080.

Falvey M. and R. D. Garreaud, 2009. Regional cooling in a warming world: Recent temperature trends in the southeast Pacific and along the west coast of subtropical South America (1979-2006). J. Geophys. Res. 114, D04102.

Feely R. A., C. L. Sabine, J. M. Hernández-Ayón, D. Ianson and B. Hales, 2008. Evidence for upwelling of corrosive "acidified" water onto the continental shelf. Science 320, 1490-1492.

Good S. A., G. K. Corlett, J. J. Remedios, E. J. Noyes and D. T. Llewellyn-Jones, 2007. The global trend in sea surface temperature from 20 years of advanced very high resolution radiometer data. J. Climatol. 20, 1255-1264.

Gutiérrez D., I. Bouloubassi, A. Sifeddine, S. Purca, K. Goubanova, M. Graco, D. Field, L. Méjanelle, F. Velazco, A. Lorre, R. Salvatteci, D. Quispe, G. Vargas, B. Dewitte and L. Ortlieb, 2011. Coastal cooling and increased productivity in the main upwelling zone off Peru since the mid-twentieth century. Geophys. Res. Lett. 38, L07603.

Helly J. and L. Levin, 2004. Global distribution of naturally occurring marine hypoxia on continental margins. Deep-Sea Res. Pt. I 51, 1159-1168.

Lluch-Belda D., P. Del-Monte-Luna and S. E. Lluch-Cota, 2009. 20th century variability in the Gulf of California SST. Cal. Coop. Ocean. Fish. 50, 147-154.

Lluch-Cota S. E., A. Parés-Sierra, V. O. Magaña-Rueda, F. Arreguín-Sánchez, G. Bazzino, H. Herrera-Cervantes and D. Lluch-Belda, 2010. Changing climate in the Gulf of California. Prog. Oceanogr. 87, 114-126.

Mantua N. J., S. R. Hare, Y. Zhang, J. M. Wallace and R. C. Francis, 1997. A Pacific interdecadal climate oscillation with impacts on salmon production. B. Am. Meteorol. Soc. 78, 1069-1079.

Millennium Ecosystem Assessment, 2005. Ecosystem and human well-being: Synthesis. Island Press, Washington DC, $137 \mathrm{pp}$.

Monteiro P., A. Vanderplas, J. Mélice and P. Florenchie, 2008. Interannual hypoxia variability in a coastal upwelling system: Ocean-shelf exchange, climate and ecosystem-state implications. Deep-Sea Res. Pt. I 55, 435-450.

Penland C. and L. Matrosova, 1998. Prediction of tropical Atlantic sea surface temperatures using linear inverse modeling. J. Climate 11, 483-496.

Pérez F. F., X. A. Padín, Y. Pazos, M. Gilcoto, M. Cabañas, P. C. Pardo, M. D. Doval and L. Farina-Busto, 2010. Plankton response to weakening of the Iberian coastal upwelling. Glob. Change Biol. 16, 1258-1267.

R Development Core Team, 2011. R: A Laguage and environment for statistical computing. R Foundation for Statistical Computing; Vienna, 1706 pp. Available at: http://www.R-project.org/.

Snyder M. A., L. C. Sloa, N. S. Diffenbaugh and J. L. Bell, 2003. Future climate change and upwelling in the California Current. Geophys. Res. Lett. 30, 1-4. 
Strong A. E., G. Liu, C. M. Eakin, J. D. Christensen, W. Skirving, D. K. Gledhill, F. S. Heron and J. A. Morgan, 2008. Implications for our coral reefs in a changing climate over the next few decades - Hints from the past 22 years. Proceedings of the 11th International Coral Reef Symposium. Fort Lauderdale, Florida, 1130-1334.

Trenberth K. E. and D. P. Stepaniak, 2001. Indices of El Niño evolution. J. Climate 14, 1697-1701.

Trenberth K. E., P. D. Jones, P. Ambenje, R. Bojariu, D. Easterling, A. Klein Tank, D. Parker, F. Rahimzadeh, J. A. Renwick, M. Rusticucci, B. Soden and P. Zhai, 2007. Observations: surface and atmospheric climate change. In: Climate Change 2007: The physical science basis. Contribution of Working Group I to the Fourth Assessment Report of the Intergovernmental Panel on Climate Change (S. Solomon., D. Qin, M. Manning, Z. Chen, M. Marquis, K.B. Averyt, M. Tignor and H.L. Miller, Eds.). Cambridge University Press, Cambridge, United Kingdom and New York, 235-336.

Verbesselt J., R. Hyndman, G. Newnham and D. Culvenor, 2010. Remote sensing of environment detecting trend and seasonal changes in satellite image time series. Remote Sens. Environ. 114, 106-115.

Verbesselt J., A. Zeileis, and M. Herold, 2012. Near real-time disturbance detection using satellite image time series. Remote Sens. Environ. 123, 98-108. 